\title{
Attitudes Towards Foreign-born Settlers: Finland in a Comparative Perspective
}

\author{
HEIKKI ERVASTI, Ph.D., Docent \\ Department of Social Policy \\ University of Turku, Finland
}

\begin{abstract}
The present paper focuses on the Finnish attitudinal climate towards foreign-born settlers, i.e. immigrants, refugees and asylum seekers in a comparative perspective. Two theoretical approaches are tested: 1) the socio-economic explanation in which prejudice is seen as an outcome of the original majority population fearing a decline of their socio-economic position, and 2) a culturally oriented explanation which refers to fears concerning the possible negative cultural effects of immigration. Using survey data from the first round of the European Social Survey (ESS) on Finland and 18 other countries, we find that at the most general level, Finns do hold comparatively negative attitudes towards increasing the number of immigrants in Finland. However, as we turn to more specific items on economic and especially cultural threat, we find that Finns are as tolerant or even more tolerant than other Europeans. Multivariate analyses show that both socio-economic factors and values, ideologies and religiosity may generate prejudice. The two theoretical approaches should, thus, not be taken as alternatives but rather as complementary theories.
\end{abstract}

Keywords: racism, prejudice, immigration, Finland

\section{Introduction}

"Xenophobia is as terrifying and as untouchable as a ghost, but more lifelike and much more vivid”'(Frindte et al. 1996, 463).

Recent surveys indicate that negative attitudes towards immigrants, xenophobia and even racism are widespread across Europe. According to the Eurobarometer 1997 Survey, 81 percent of Belgians, 78 percent of Finns and 75 percent of the French identify themselves as racist at least to a certain extent (Scheepers et al. 2002). According to an analysis of the Eurobarometer 2000 data, a majority of Europeans voice concern over minorities, fearing that they are threatening social peace and 
welfare. This percentage increased over the period 1997-2000 (Thalhammer et al. 2001). More explicitly these attitudes - although involving only small extremist minorities - are reflected in the outbreaks of at times even deadly racist violence recently reported in most parts of Europe (see Pettigrew 1998, 96-98).

The focus of this article is on the attitudinal climate concerning foreign-born settlers, i.e. immigrants, refugees and asylum seekers in Finland. The main question is whether Finns hold harsher or more liberal attitudes towards foreign-born settlers in comparison with other Nordic countries and Eastern-Central and Southern-Central European countries. Moreover, we seek to find out the reasons for the possible differences in prejudice between different segments of the population and between Finland and the other European countries.

What makes Finland an especially interesting case is that compared with the rest of Europe, the Finnish population is very homogenous. The Swedish-speaking minority of 6 percent is significant for historical reasons, and the old Sami and Romany minorities number about 4,400 and 5,500, respectively. In the late 80s, Finland experienced an influx of immigrants, refugees and asylum seekers from Asia, Africa, Latin America and the former Soviet Union. In the years 1990 to 2002 the size of the population of foreign origin increased threefold, but it still totals less than 3 percent of the total population. The largest groups of foreign-born settlers in Finland come from Russia, Estonia, Sweden and Somalia (see e.g. Heikkilä \& Peltonen 2002).

The structure of this article is as follows. First, we shall see what are the theoretical causes and determinants of negative attitudes towards immigration and xenophobic thinking. We will seek the answer in two groups of theories. The first group of theories emphasizes the fear of socio-economic threat posed by immigrants. In the second group of theories, the fears of cultural threat are brought to the fore. These theories are put to an empirical test by using recent cross-sectional survey data from Finland and 19 other European countries gathered in the European Social Survey - ESS (Jowell et al. 2003). Finally, the results of the empirical analysis are discussed.

\section{Explanations of attitudes towards immigrants}

Questions about the causes of negative attitudes towards immigrants and xenophobia have continued to stimulate research as well as arouse controversy among social scientists for decades. Basically, two lines of theoretical arguments can be distinguished: 1) the socio-economic explanation in which the main reason for prejudice is seen as an outcome of the original majority population fearing loss of their socio-economic position, and 2) a culturally-oriented explanation which refers to fears of the possible cultural affect of immigration. In this section, both types of explanations will be discussed in turn. 


\section{Socio-economic threat}

Socio-economic explanations of the origins of xenophobia form the most traditional group of explanations. Ever since the days of Sherifs (1953), the existence of prejudice has been explained by the competition for scarce resources. Foreign-born settlers pose a threat to the material well-being of the original majority population. Like Giles and Hertz $(1994,317)$ put it, the relationships between different ethnic groups are viewed 'as a function of their competitive positions' in this theory (see also Canetti-Nisim \& Padahzur 2003, 312). Immigrant workers coming from countries with clearly lower standards for working conditions and wages may distort the labor market of the country receiving foreign labor.

Issues of economic well-being also lead to questions of distributive justice and fairness. This is especially emphasized in the theory of relative deprivation, which is closely connected to the economic threat hypothesis. According to the theory of relative deprivation, the beliefs of individuals "represent a relationship between their expectations and the achievement relative to others in the same boat with them" (Stouffer et al. 1949, 251). Negative sentiments emerge as people feel deprived in comparison with some standard, or with the real or imagined condition of other people (Williams 1975). Especially when a given reference group is rewarded more than one's own in relation to their efforts or needs, people's idea of what is just and fair will be provoked. The experience of relative deprivation may lead to a negative view of the system that allows this, or negative attitudes toward the group as such - or both (Hernes \& Knudsen 1992). Thus, true or false examples of social security and other benefits too easily available to immigrants and asylum seekers often found in the media and newspapers probably generate much anger and negative sentiments among the general public.

The perceived economic threat may be of special importance in Finland. During the international economic crisis in the early 1990s, the Finnish unemployment rate soared more than six-fold within a few years (see Ervasti 2002). The levels of unemployment have declined steadily since those days, but still the Finnish unemployment rate is among the highest in the EU hemisphere. Indeed, earlier national Finnish surveys (Jaakkola 1995; 1999; Söderling 1997) show that the attitudes of Finns took on a clearly harsher tone during the economic decline in the early 1990s. As the economy started to grow again, Finns adopted more positive attitudes towards immigrants, although by the end of the 1990s, the Finnish attitudinal climate was not as positive as it had been in the late 1980s (Jaakkola 1999). 


\section{Cultural threat}

However, empirical studies do not consistently give support to socio-economic explanations. For example Van der Brug et al. (2000) find that social and economic variables were mostly insignificant in explaining support for anti-immigrant parties in seven European countries. Similar results have been found in other studies, too (e.g. Knigge 1998; Scheepers et al. 2002). As an alternative to socio-economic explanations, cultural aspects have been stressed as important factors accounting for the existence of prejudice. According to this view, the origins of prejudice are related to cultural tensions between ethnic groups: foreigners are viewed as a potential threat to national identity and social order and, most importantly, to the values cherished by the original majority population.

The idea of including a value component in the theoretical understanding of attitudes towards foreign-born settlers owes very much to Milton Rokeach's more general theory of out-group tolerance. Rokeach (1968) suggests that prejudice derives from the assumption that members of an out-group hold beliefs, attitudes and values that differ from one's own. Very often the members of the in-group form generalizations and stereotypes of the out-groups. Moreover, the picture that the members of the in-group form about the values and intentions of the out-group is not always correct. Many examples illustrate that cultural misunderstandings can lead to ethnic prejudice and hostility, the murder of James Cook in 1779 by the Hawaiians being the most exotic example of this (Hagendorn 1993, 27).

Several studies have identified the groups of population that most eagerly cherish traditional and conventional values and at the same time resist changes. In the early 1950s Adorno and his colleagues (1950) argued that certain people were prejudiced because their prejudices meet certain needs deriving from their personality. According to this theory, authoritarianism is a personality construct deriving from a person's childhood, especially in strongly disciplinarian families. In adulthood, the possessor of an authoritarian personality has a high amount of pent-up anger which, because of basic insecurity, manifests itself in a displaced aggression against powerless groups.

According to critics the main problem of the theory on the authoritarian personality is that the theory lacks a secure theoretical grounding, which severely limits our understanding of authoritarianism (Feldman 2003). Ray (1990) suggests that authoritarianism is nothing more than simply an old-fashioned orientation, which correlates strongly with racial prejudice. Moreover, as authoritarianism is a learned and not a genetic characteristic, it can easily be related to value priorities. Recent studies have shown that authoritarianism correlates strongly with security, conformity and traditional value priorities (Knafo 2003; Bamberg et al. 2001). So, rather than among authoritarians, "prejudice and intolerance should be observed among 
those who value social conformity and perceive a threat to social cohesion", as Feldman $(2003,41)$ puts it.

All in all, like the socio-economic explanation, also the value component may have a special importance in the Finnish context. People all over the world relate foreigners to such worries as rising crime rates, drug problems, diseases like AIDS, and the fear of losing traditional elements of the national culture, work ethic, religion etc. Thus, it may well be the case that the fear of these problems is comparatively strong in Finland, a country with an exceptionally low number of HIV positive persons, practically non-existent organized crime and a comparatively modest level of drug problems.

\section{Hypotheses}

Based on the hypotheses of socio-economic threat and cultural threat, several hypotheses can be formulated. More precisely, the hypotheses to be tested in this study deal with socio-economic status (education, occupational status, labor market status and financial situation) and gender. Moreover, we will test the effects of conformity and traditional value priorities, religiosity, political orientation, contact with immigrants, place of residence and age. For each factor, we can make the following assumptions:

Socio-economic status. According to socio-economic explanations, stratification hierarchies are the most important determinant of prejudice. Persons with a low-scale social and economic background are supposed to be more prone to fearing foreigners and expressing xenophobic sentiments than persons with a high socio-economic status. More specifically, the theory of relative deprivation suggests that those who experience adversity or fewer rewards than groups with whom they compare themselves, are most likely to develop prejudices and a fear of foreigners.

Moreover, education may have a value-based effect on prejudice, too. Educational institutions may be regarded as vital propagators of democratic and tolerant values. Moreover, higher education may offer broader perspectives with more knowledge about foreign cultures, which in turn reduce prejudice (Jackman \& Muha 1984).

Gender. According to several earlier studies the effect of gender has been found to be a significant predictor of attitudes towards immigrants. These studies indicate that compared with men, women have developed more tolerant attitudes towards immigrants. This may be explained by a certain version of the theory of relative deprivation (Hernes \& Knudsen 1992): many highly visible male foreigners among the otherwise homogenous population may increase the competition for women. In other words the men of the original majority population find themselves in a "less favorable position in the sex market" (Hernes \& Knudsen 1992, 127). 
Age. Contradictory hypotheses can be posed about the effects of age. From the perspective of socio-economic explanations, the young age groups can be expected to show more prejudice than middle-aged and elderly people. The economic position of youth is often insecure. However, regarding the value priorities typical for each generation, age may have the opposite effect. From one generation to another, value priorities are often regarded as developing in a less materialistic and socially more liberal and tolerant direction (Inglehart 1997). This would lead us to suggest, in line with some earlier studies (e.g. Eisinga et al. 1999; Raijman et al. 2003) that the younger a person is, the less prejudiced she or he is.

Conservation value priorities, religiosity and political orientation. The cultural threat hypothesis directly suggests a hypothesis about the effects of conformity and traditional value priorities. These values can be assumed to increase prejudice.

Moreover, the effects of religiosity and political (left-right) orientation are also worth noting. Most religious groups espouse tolerance and love towards members of other groups. However, according to previous research the relationship between religious beliefs and prejudice is ambiguous. On the one hand, there are studies showing that religious people tend to be more prejudiced than non-religious people (Allport \& Ross 1967; Altemeyer 2003; Altemeyer \& Hunsburger 1992). On the other hand, there is also evidence suggesting that there is either a slightly positive correlation between religious beliefs and prejudices (Jaakkola 1999; 1995), or no correlation when controlled for other factors (Eisinga et al. 1999).

Political conservatism has been shown to correlate with xenophobia and racial prejudice. For example, Sniderman and his colleagues (1991, 423) conclude that, once again, political conservatism is found in their study "to be correlated with opposition to policies to assist blacks and with support for negative images of blacks as lazy and irresponsible". Of course, opposition to government spending may be inspired not by racism but rather by more general conservatism and right-wing thinking. However, there is also evidence that political party affiliation directly affects attitudes towards immigrants and asylum seekers so that those supporting the leftist parties hold clearly more positive attitudes than those on the right (Raijman et al. 2003; Jaakkola 1995, 64-65; 1999; Chandler \& Tsai 2001; Söderling 1997).

Contact with representatives of foreign cultures, place of residence and marital status. Although the theories discussed above do not lead to assumptions about the effects of personal contacts with immigrants, place of residence or marital status on prejudice, these factors are included in the analysis as controls. Empirically the most well-grounded explanation of the background of prejudice is the so-called contact hypothesis (see Bratt 2002; Spencer-Rodgers \& McGovern 2002; Söderling 1997, 20). According to this simple explanation, contact between groups reduces 
intergroup prejudice, i.e. the more the members of the in-group are in contact and personally know members of the out-group, the less prejudice they show. Moreover, the place of residence and marital status may also affect attitudes towards foreignborn settlers. The general assumption is that those living in big cities have the most liberal attitudes towards immigrants whereas those living in rural areas are the most prejudiced (see Jaakkola 1995). The role of marital status has been examined in only a few earlier studies. However, there is evidence that married persons are less prejudiced than unmarried persons (see Raijman et al. 2003).

\section{Data and methods: The European Social Survey}

Data for this analysis comes from the first round of the European Social Survey - ESS (Jowell et al. 2003). The European Social Survey is a new, academicallydriven social survey designed to chart and explain the interaction between Europe's changing institutions and the attitudes, beliefs and behavior patterns of its diverse populations. The questionnaire contains core modules and rotating modules, one of which was specially dedicated to attitudes on immigration. The countries included in this analysis are the first 19 countries having finished the first round of fieldwork.

The survey employs the most rigorous methodologies. Optimal comparability was the target issue in sampling, fieldwork procedures and translation, as well as in data preparation. Random probability samples representing eligible residential populations aged 15 or more were drawn in each country. Specially trained interviewers conducted the personal interviews. The response rates were generally higher than 65 percent, with the exceptions of Ireland (64.5\%), Germany (57.1\%), the U.K. (55.5\%), Spain (53.2\%), Italy (43.7\%) and Switzerland (33.5\%).

\section{Dependent variables}

Three separate scales were used as the dependent variables. The first dependent variable consists of six items in which the respondents were asked on the most general level whether they would like to allow more or less immigrants from different ethnic groups to come to their countries from different parts of the world (see Table 1). The second scale, consisting of three items, measures the perception of economic threat posed by immigration. The respondents were asked if they think that immigrants take jobs away, if immigrants take out more taxes and services than they put in and if immigration is bad for a country's economy (Table 2). The third scale measures the possible negative cultural effects of immigration on national cultures. The six items used in this scale treat the issue of culture in a wider sense, i.e. the respondents were posed questions about the possible effects of immigration on not only cultural

\footnotetext{
${ }^{1}$ For translation strategy and other details see www.europeansocialsurvey.org
} 
life but also on the crime problem and tension. In addition, the respondents were asked if they think it would be better for their country if almost everyone shares the same customs and traditions, if there are not many different religions and if almost everyone speaks one common language (Table 3$)^{2}$

\section{Independent variables}

To test the hypotheses posed above, measures of socio-economic status, gender, age, religiosity, political orientation, place of residence and marital status were used as the independent variables. Socio-economic status was measured by education (in years spent in education), occupational status (in six groups ${ }^{3}$ ) and household income (in three groups). In addition to personal income, the respondents were asked more generally how satisfied they are with the present economic situation of their country on a ten-point scale. Moreover, as a measure of economic status, we controlled for whether or not the respondent had experienced unemployment during the last five years.

Age was measured straightforwardly in years. The measure of religiosity is based on an item on the frequency of praying apart from at religious services. Those praying at least once a week were coded as being religious and those praying less than weekly were coded as non-religious. Political orientation was measured with a tenpoint left-right scale. Place of residence distinguishes between those living in a rural area and those living in urban surroundings and marital status between those never married, divorced or widowed and those currently married. Finally, as a control we included a variable measuring how many immigrant friends the respondent has. This variable consists of three categories: those having no immigrant friends, those having a few immigrant friends and those having several friends of foreign origin.

The measure on conservation value priorities is based on six items from the Portraits Questionnaire (PQ) developed by Schwartz (1997) as a component of his more general theory of basic value priorities. In these items the respondents were described personal characteristics and behavior reflecting certain value priorities and the respondents could choose on a six-point scale how well these descriptions fit themselves (from "very much like me" to "not like me at all"). The exact wordings of the five items were the following: 1) it is important to him to live in secure surroundings. He

\footnotetext{
2 The scales proved to be highly reliable with Cronbach's alphas above .90 for the first scale in all groups of countries, and around .70 for the second and the third scale.

3

${ }^{3}$ The grouping of occupations is based on the class-scheme of Eriksson and Goldthorpe (1992). This scheme distinguishes between six groups: service class I, service class II, routine non-manual class, skilled manual workers, unskilled manual workers and the self-employed. However, in this analysis the service classes were combined into one group and an additional group 'other/unknown' was formed of the respondents for whom we do not have the occupational code.
} 
avoids anything that might endanger his safety"; 2) "It is important to him that the government ensures his safety against all threats. He wants the state to be strong so it can defend its citizens"; 3) "he believes that people should do what they are told. He thinks people should follow rules at all times, even when no one is watching"; 4) "it is important to him always to behave properly. He wants to avoid doing anything people would say is wrong"; 5) "It is important to him to be humble and modest. He tries not to draw attention to himself"; and 6) "Tradition is important to him. He tries to follow the customs handed down by his religion or his family". 4

\section{Method}

As the dependent variables are scales and the independent variables are both continuous (age, education, satisfaction with the economy, left-right scale and conservation values) and categorical variables (gender, experince of unemployment, number of emigrant friends, occupation, income, place of residence, marital status and religiosity), analysis of covariance was employed as the multivariate method (see Tabachnick \& Fidell 2001, chapter 8). Analysis of covariance was conducted first to examine the effects of the background variables on the dependent variables in Finland, other Nordic countries (Sweden, Norway and Denmark), Central European countries (Switzerland, Germany, the U.K, Ireland, Luxembourg and the Netherlands), Mediterranean and/or Latin-Rim countries (Spain, Greece, Italy, Israel and Portugal) and Eastern Europe (the Czech Republic, Hungary, Poland and Slovenia) separately. Finally, all groups of countries were included in the same analysis.

\section{Results}

\section{Descriptive findings}

The percentages of those allowing only few or no immigrants in their countries are shown in Table 1. At the most general level Finns hold harsh attitudes towards receiving immigrants in comparison with other Europeans. Only around the Mediterranean and in Eastern Europe are there countries, where the general public shows more negative attitudes towards immigrants than the Finns do. These countries are Greece, Portugal and Hungary. Judged by the mean of the scale consisting of all the variables measuring attitudes towards receiving immigrants, Sweden, Switzerland, Israel and Ireland are the four countries with the most positive attitudinal climate.

\footnotetext{
${ }^{4}$ Cronbach's alphas were above .70 in all groups of countries except the Eastern European countries where it was .696.
} 


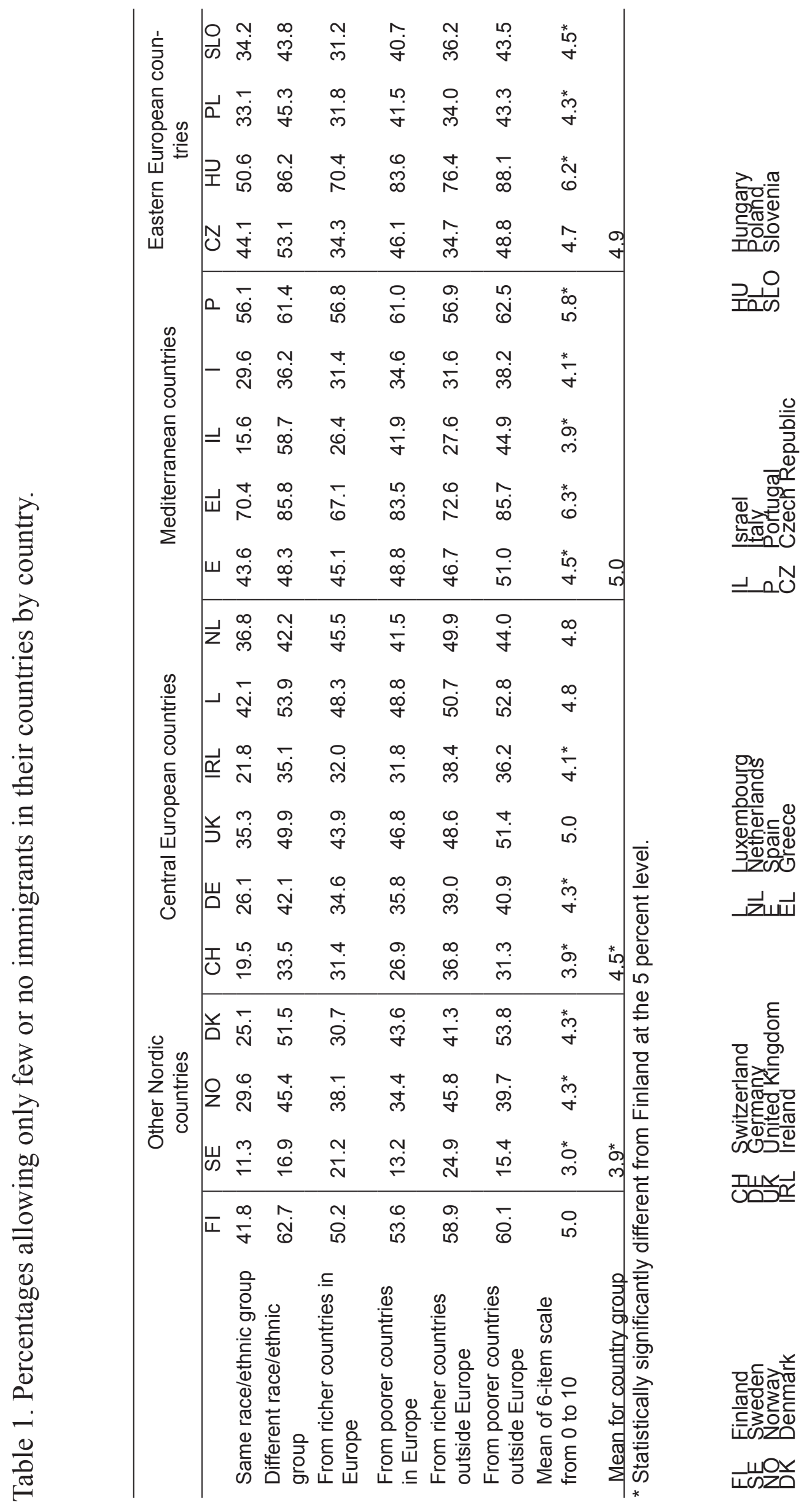




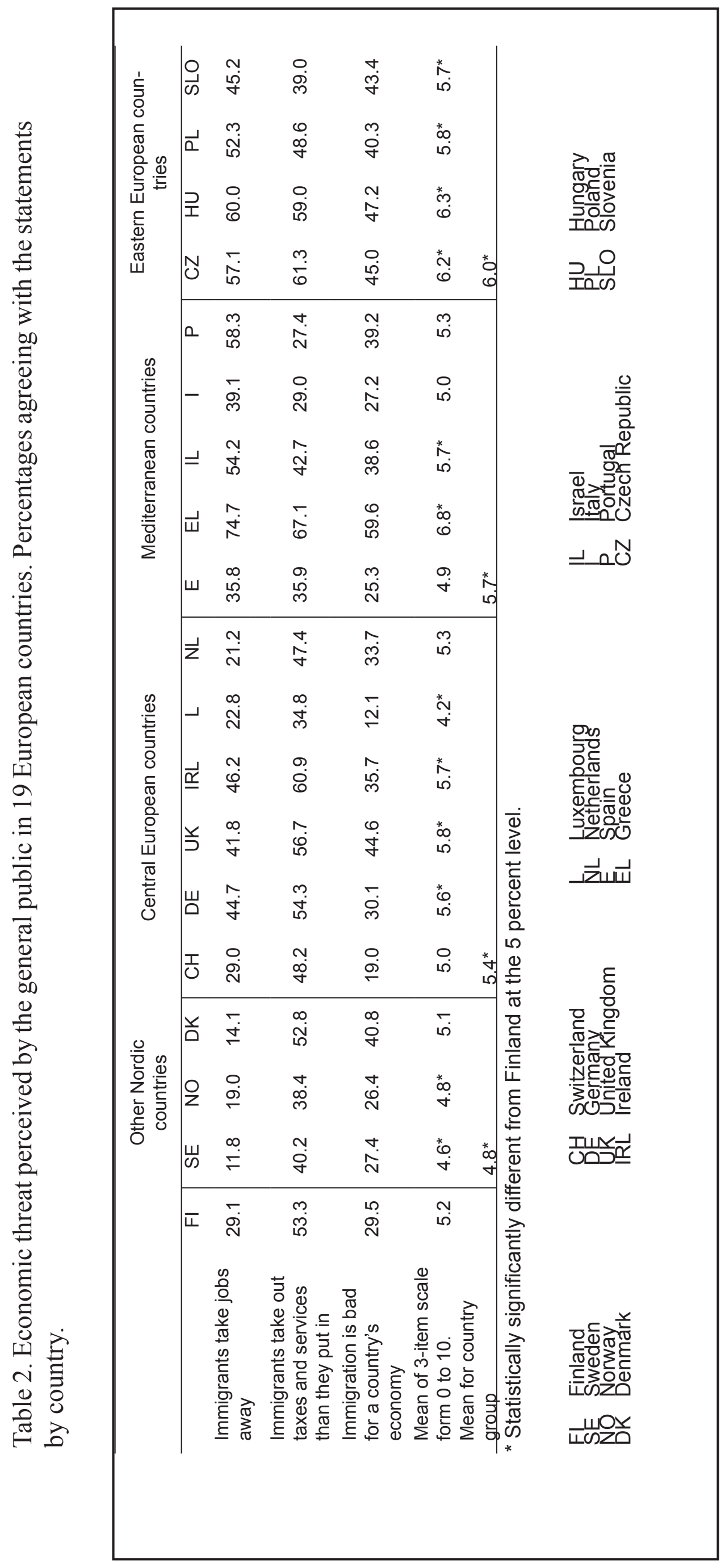


Moreover, public attitudes in all European countries depend on which group of immigrants is in question. In almost all countries the general public shows the most positive attitudes towards receiving immigrants who belong to the same ethnic group as themselves. Similarly, in all countries people would receive immigrants from Europe rather than outside Europe. These findings correspond to the results of prior research in a variety of countries showing that people have systematic and highly consensual rankings for ethnic out-groups (see Duckitt 1992; Mullick \& Hraba 2001; Hagendoorn et al. 1998; Jaakkola 1995, 74-75; see also Hagendoorn 1993, 32-33).

However, if we look at the distributions of the variables measuring the assumption that immigration poses an economic threat to the receiving country in Table 2, the attitudes of Finns do not seem so negative in a European comparison. Only in seven countries is the mean of the scale measuring economic threat lower than in Finland. Interestingly enough, the proportion of those worrying that immigrants take jobs away, does not correlate with the actual level of unemployment. The proportions of Finns agreeing with the statements referring to the bad economic influence of immigration or the possible tax burden caused by immigration are below the average of the 19 countries under scrutiny in this research.

Turning to attitudes concerning the alleged threat on national cultures posed by immigration in Table 3, we can see that very few Finns are worried about immigration undermining Finland's cultural life. Only five percent of the Finnish population agree with this statement. In all the other countries this proportion is higher than in Finland. Concerns of a rising crime rate and other tension and wishes for shared customs and traditions, one common language and religion are around the European average among the Finnish general public. All in all, judged by the mean of the scale consisting of all variables measuring the alleged cultural threat posed by immigration, Finns, as well as the general public in the other Nordic countries, appear to be among the most tolerant nations in Europe.

\section{Multivariate analyses}

To see the effects of the background variables, analyses of covariance were conducted. The dependent variables are the scales measuring the general acceptance of immigration, the possible economic threat of immigration and the cultural threat. The multivariate analyses were conducted separately for Finland, the other Nordic countries, the Central European countries, the Mediterranean countries and the Eastern European countries. Finally, all countries were included in the same model. The results of the analysis with the dependent variable general attitudes towards receiving immigrants are depicted in Table 4. 


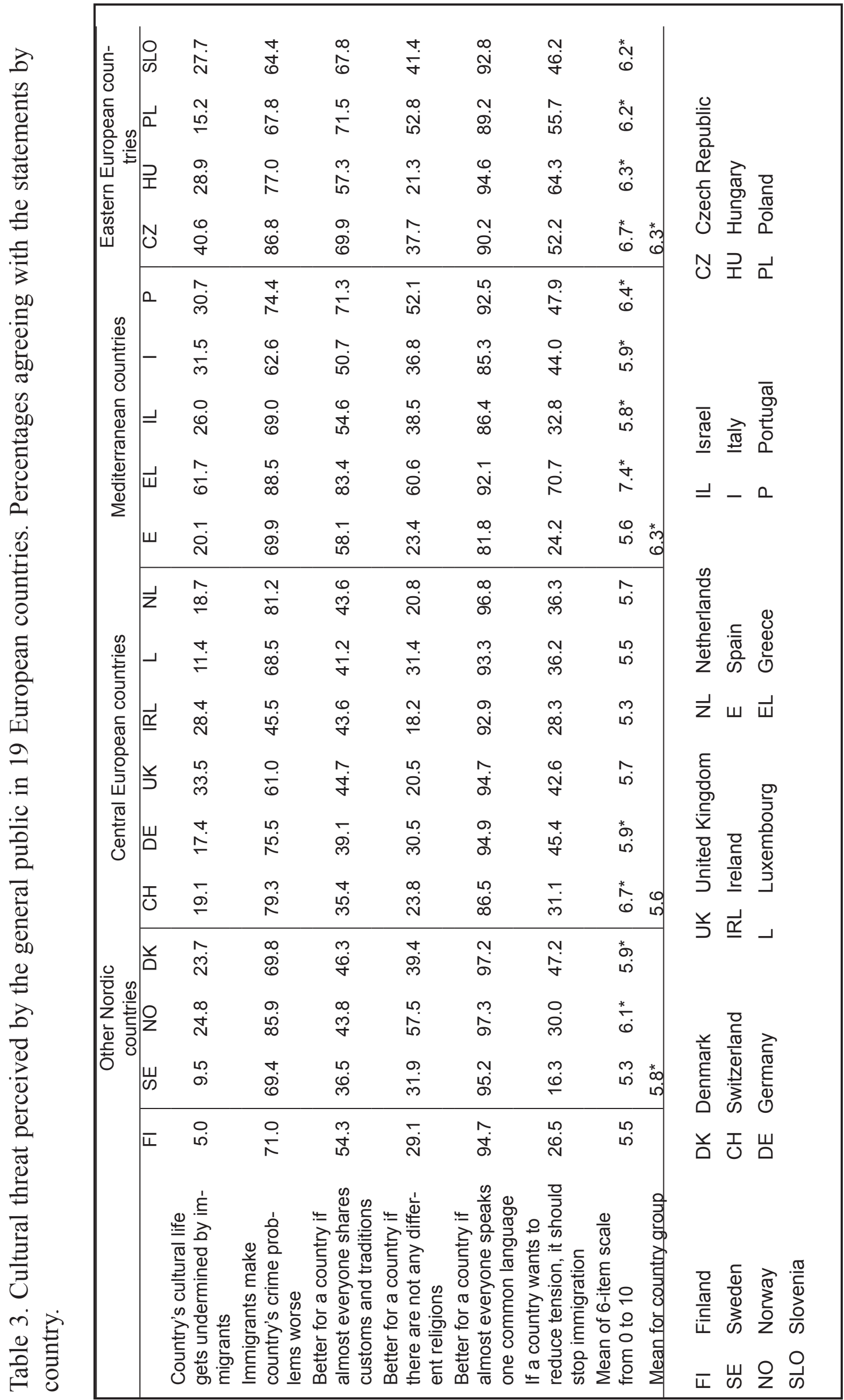


As shown in Table 4, personally knowing immigrants is the best predictor of attitudes towards receiving immigrants. This holds for all the countries in this analysis. The other important factors are education, position on the left-right scale, authoritarianism and satisfaction with one's own country's economic situation. These findings give support to both the relative deprivation theory and the value-based theory of prejudice: prejudice is simultaneously a function of both socio-economic and cultural factors. Generally, it can be said that the less educated a person is, the more rightist political opinions he or she holds, the more authoritarian personality characteristics he or she has and the less satisfied with his or her economic situation he or she is, the more negative a stance he or she holds about receiving immigrants in his or her country. Moreover, the white-collar workers belonging to the service classes hold more liberal attitudes towards immigration than the other occupational groups.

In accordance with the relative deprivation theory, unemployment seems to increase having a negative stance towards immigration. However, this effect is statistically significant only in Finland and Central European countries.

Perhaps a little bit surprisingly, the gender of the respondent has only limited explanatory power on attitudes towards immigration. Only in Central Europe do we find a statistically significant difference between men and women. Also the level of income, place of residence, marital status and religiosity have only limited effects on attitudes towards immigrants, and mainly these effects can be found outside the Nordic countries.

Regarding the variation of fears about the possible economic threat posed by immigration, the multivariate results are shown in Table 5. Again, we find strong effects of personally knowing immigrants. In line with the relative deprivation theory, also education, economic satisfaction and conformity/traditional value priority have a clear effect on the dependent variable. But again, not only the theory of relative deprivation gains support: this time religiosity, too, has an effect on all the countries. In all but the Mediterranean countries, this effect is negative, in other words those with a more religious world view have more positive attitudes towards immigrants in the sense of economic threat.

Finally, the results of the multivariate analysis on the fear of the possible culturally undermining effects of immigration are depicted in Table 6. Also in this analysis, the most efficient predictors of attitudes towards immigration are personally knowing immigrants, education, economic satisfaction, the left-right scale and authoritarianism. This time we also find a clear effect of gender in most countries. Women are less worried about the possible negative effects of immigration on national culture than men. 
Table 4. Determinants of negative attitudes towards allowing immigrants in the respondent's country. Analysis of covariance.

\begin{tabular}{|c|c|c|c|c|c|c|}
\hline & Finland & $\begin{array}{c}\text { Nordic } \\
\text { countries }\end{array}$ & $\begin{array}{l}\text { Central } \\
\text { Europe }\end{array}$ & $\begin{array}{l}\text { Mediter- } \\
\text { ranean } \\
\text { countries }\end{array}$ & $\begin{array}{l}\text { Eastern } \\
\text { Europe }\end{array}$ & $\begin{array}{c}\text { All coun- } \\
\text { tries }\end{array}$ \\
\hline Intercept & $4.68^{* \star *}$ & $3.64^{* * *}$ & $5.04^{* \star *}$ & $5.50^{* * *}$ & $6.16^{* * *}$ & $5.61^{* * *}$ \\
\hline Male & 15 & .11 & $-.12^{\star *}$ & .03 & -.03 & -.04 \\
\hline Female & 0 & 0 & 0 & 0 & 0 & 0 \\
\hline Experience of unemployment & $.25^{\star}$ & -.06 & $.11^{*}$ & .07 & .03 & $.07^{*}$ \\
\hline No experience of unemployment & 0 & 0 & 0 & 0 & 0 & 0 \\
\hline Several immigrant friends & $-1.11^{* * *}$ & $-.94^{* * *}$ & $-1.02^{* * *}$ & $-1.70^{* * *}$ & $-.54^{* * *}$ & $-1.20 * * *$ \\
\hline A few immigrant friends & $-.46^{* * *}$ & $-.50^{\star \star \star}$ & $-.48^{* * *}$ & $-.87^{* \star *}$ & $-.55^{\star * *}$ & $-.61^{* * *}$ \\
\hline No immigrant friends & 0 & 0 & 0 & 0 & 0 & 0 \\
\hline Other occupation / unknown & -.48 & -.11 & $-.47^{* * *}$ & .03 & -.24 & $-.20^{* \star *}$ \\
\hline Self-employed & .15 & $-1.03^{* * *}$ & $-.26^{*}$ & .13 & .09 & -.08 \\
\hline Service class & $-.39^{*}$ & $-.59^{\star \star *}$ & $-.48^{* * *}$ & -.16 & $-.48^{* * *}$ & $-.42^{* * *}$ \\
\hline Routine non-manual & -.16 & $-.21^{*}$ & $-.34^{* * *}$ & $-.24^{*}$ & $-.31^{* *}$ & $-.28^{* * *}$ \\
\hline Skilled manual worker & .08 & .18 & -.03 & $.37^{* *}$ & -.14 & .09 \\
\hline Unskilled manual worker & 0 & 0 & 0 & 0 & 0 & 0 \\
\hline Unknown income & -.10 & -.08 & -.12 & $.23^{*}$ & $-.48^{* * *}$ & -.03 \\
\hline High income & .11 & -.11 & $-.47^{* * *}$ & -.03 & $-.78^{* * *}$ & $-.32^{* * *}$ \\
\hline Middle income & .04 & .09 & $-.25^{\star * *}$ & -.06 & $-.41^{* * *}$ & $-.15^{\star \star *}$ \\
\hline Low income & 0 & 0 & 0 & 0 & 0 & 0 \\
\hline Rural & .11 & $.21^{* *}$ & .05 & -.09 & $.20^{\star *}$ & $.08^{* *}$ \\
\hline Urban & 0 & 0 & 0 & 0 & 0 & 0 \\
\hline Never married & -.05 & -.06 & $-.21^{* * *}$ & $-.24^{*}$ & $-.39^{* * *}$ & $-.23^{* * *}$ \\
\hline Divorced or widowed & .26 & -.12 & -.03 & -.24 & .08 & -.03 \\
\hline Married & 0 & 0 & 0 & 0 & 0 & 0 \\
\hline Religious & -.20 & .05 & $-.41^{* * *}$ & $.89^{\star \star \star}$ & $-.46^{* * *}$ & $-.07^{*}$ \\
\hline Non-religious & 0 & 0 & 0 & 0 & 0 & 0 \\
\hline Age & $.23^{* * *}$ & .04 & .01 & $-.06^{*}$ & $.06^{*}$ & $.02^{*}$ \\
\hline Education & $-.91^{* * *}$ & $-.86^{* * *}$ & $-.80^{\star * *}$ & $-.88^{* * *}$ & $-.67^{* * *}$ & $-.86^{\star * *}$ \\
\hline Satisfaction with economy & $-1.11^{* * *}$ & -.17 & $-.92^{* * *}$ & $-.89^{\star * *}$ & $-.64^{* * *}$ & $-.71^{* * *}$ \\
\hline Left-right scale & $.83^{* *}$ & $1.70^{* * *}$ & $1.55^{* * *}$ & $.56^{* * *}$ & .05 & $.97^{* * *}$ \\
\hline Conservation values & $1.30^{* * *}$ & $1.46^{* * *}$ & $1.67^{* * *}$ & $1.20^{* \star *}$ & $.64^{* *}$ & $.144^{* * *}$ \\
\hline Nordic countries & - & - & - & - & - & $-.79^{* * *}$ \\
\hline Central European countries & - & - & - & - & - & $-.49^{* * *}$ \\
\hline Mediterranean countries & - & - & - & - & - & $-.30^{\star * *}$ \\
\hline Eastern European countries & - & - & - & - & - & $-.49^{* \star *}$ \\
\hline Finland & - & - & - & - & - & 0 \\
\hline $\mathrm{R}^{2}$ & .22 & .18 & .18 & .20 & .13 & .18 \\
\hline
\end{tabular}


Table 5. Determinants of economic fears posed by immigration. Analysis of covariance.

\begin{tabular}{|c|c|c|c|c|c|c|}
\hline & Finland & $\begin{array}{l}\text { Nordic } \\
\text { coun- } \\
\text { tries }\end{array}$ & $\begin{array}{l}\text { Central } \\
\text { Europe }\end{array}$ & $\begin{array}{l}\text { Mediter- } \\
\text { ranean } \\
\text { coun- }\end{array}$ & $\begin{array}{l}\text { Eastern } \\
\text { Europe }\end{array}$ & $\begin{array}{c}\text { All } \\
\text { coun- } \\
\text { tries }\end{array}$ \\
\hline Intercept & 2.18 & -3.82 & $-4.469^{*}$ & $-13.20^{* *}$ & $13.04^{* *}$ & $-3.84^{*}$ \\
\hline Male & .03 & -.06 & $-.18^{* * *}$ & .02 & $-.12^{*}$ & $-.09^{* * *}$ \\
\hline Female & 0 & 0 & 0 & 0 & 0 & 0 \\
\hline Experience of unemployment & .14 & $.16^{* *}$ & $.15^{\star \star *}$ & .05 & .08 & $.10^{\star * *}$ \\
\hline No experience of unemployment & 0 & 0 & 0 & 0 & 0 & 0 \\
\hline Several immigrant friends & $-.82^{* * *}$ & $-.79^{\star * *}$ & $-.93^{\star * *}$ & $-1.27^{* * *}$ & $-.51^{* * *}$ & $-.98^{* * *}$ \\
\hline A few immigrant friends & $-.28^{* *}$ & $-.39^{* * *}$ & $-.44^{* * *}$ & $-.68^{* * *}$ & $-.28^{* * *}$ & $-.47^{* * *}$ \\
\hline No immigrant friends & 0 & 0 & 0 & 0 & 0 & 0 \\
\hline Other occupation / unknown & -.30 & $-.27^{\star *}$ & $-.33^{* * *}$ & -.06 & -.06 & $-.19^{* * *}$ \\
\hline Self-employed & .03 & -.29 & -.10 & $.73^{* \star *}$ & .05 & $.20^{* *}$ \\
\hline Service class & -.04 & $-.29^{* * *}$ & $-.35^{* * *}$ & $-.28^{* *}$ & $-.24^{* *}$ & $-.29^{* * *}$ \\
\hline Routine non-manual & .08 & $-.17^{*}$ & $-.24^{* * *}$ & -.05 & -.16 & $-.16^{* * *}$ \\
\hline Skilled manual worker & .03 & .02 & -.03 & .04 & -.02 & .01 \\
\hline Unskilled manual worker & 0 & 0 & 0 & 0 & 0 & 0 \\
\hline Unknown income & .10 & -.03 & -.03 & .11 & .06 & .02 \\
\hline High income & .12 & .01 & $-.09^{*}$ & $.20^{*}$ & $-.48^{* * *}$ & $-.07^{*}$ \\
\hline Middle income & .03 & -.06 & .03 & .12 & $-.18^{*}$ & -.05 \\
\hline Low income & 0 & 0 & 0 & 0 & 0 & 0 \\
\hline Rural & .15 & .06 & -.02 & -.06 & $.24^{* * *}$ & .02 \\
\hline Urban & 0 & 0 & 0 & 0 & 0 & 0 \\
\hline Never married & .19 & .04 & -.07 & -.05 & -.14 & $-.06^{*}$ \\
\hline Divorced or widowed & .23 & .07 & .04 & -.06 & -.01 & .04 \\
\hline Married & 0 & 0 & 0 & 0 & 0 & 0 \\
\hline Religious & $-.19^{*}$ & -.04 & $-.10^{* *}$ & $.53^{* * *}$ & $-.29^{\star * *}$ & .01 \\
\hline Non-religious & 0 & 0 & 0 & 0 & 0 & 0 \\
\hline Age & .02 & $.48^{* *}$ & $.56^{* * *}$ & $.96^{* * *}$ & -.03 & $.51^{* * *}$ \\
\hline Education & $-.49^{* * *}$ & $-.63^{* * *}$ & $-.51^{* * *}$ & $-.47^{* * *}$ & $-47^{* * *}$ & $-.53^{* * *}$ \\
\hline Satisfaction with economy & $-.19^{* * *}$ & $-.76^{* * *}$ & $-.15^{\star * *}$ & $-.19^{* * *}$ & $-.17^{* * *}$ & $-.15^{\star * *}$ \\
\hline Left-right scale & .03 & $.13^{* * *}$ & $.99^{* * *}$ & $.65^{* * *}$ & -.07 & $.71^{* * *}$ \\
\hline Conservation values & $.11^{* * *}$ & $.05^{* *}$ & $.81^{* * *}$ & $.15^{\star * *}$ & $.54^{* *}$ & $.68^{* * *}$ \\
\hline Nordic countries & - & - & - & - & - & -.09 \\
\hline Central European countries & - & - & - & - & - & $.28^{* * *}$ \\
\hline Mediterranean countries & - & - & - & - & - & $.12^{*}$ \\
\hline Eastern European countries & - & - & - & - & - & $.29^{* * *}$ \\
\hline Finland & - & - & - & - & - & 0 \\
\hline$R^{2}$ & .12 & .13 & .16 & .20 & .12 & .18 \\
\hline
\end{tabular}


Table 6. Determinants of fears for cultural threat posed by immigration. Analysis of covariance.

\begin{tabular}{|c|c|c|c|c|c|c|}
\hline & Finland & $\begin{array}{c}\text { Nordic } \\
\text { countries }\end{array}$ & $\begin{array}{l}\text { Central } \\
\text { Europe }\end{array}$ & $\begin{array}{l}\text { Mediter- } \\
\text { ranean } \\
\text { countries }\end{array}$ & $\begin{array}{l}\text { Eastern } \\
\text { Europe }\end{array}$ & $\begin{array}{c}\text { All coun- } \\
\text { tries }\end{array}$ \\
\hline Intercept & $15.06^{\star *}$ & $15.41^{* * *}$ & $12.40^{* * *}$ & -.18 & $17.69^{\star * *}$ & $11.14^{* * *}$ \\
\hline Male & $.41^{* * *}$ & $.28^{* * *}$ & $.08^{* *}$ & .07 & $.11^{*}$ & $.14^{* * *}$ \\
\hline Female & 0 & 0 & 0 & 0 & 0 & 0 \\
\hline Experience of unemployment & -.01 & .05 & $.07^{*}$ & -.05 & -.05 & .01 \\
\hline No experience of unemploy- & 0 & 0 & 0 & 0 & 0 & 0 \\
\hline Several immigrant friends & $-.53^{* * *}$ & $-.76^{* * *}$ & $-.78^{* * *}$ & $-.78^{* * *}$ & $-.46^{* * *}$ & $-.78^{* * *}$ \\
\hline A few immigrant friends & $-.26^{* * *}$ & $-.44^{* * *}$ & $-.38^{* * *}$ & $-.41^{* * *}$ & $-.29^{* * *}$ & $-.40^{* * *}$ \\
\hline No immigrant friends & 0 & 0 & 0 & 0 & 0 & 0 \\
\hline Other occupation / unknown & -.28 & $-.18^{*}$ & $-.16^{* *}$ & .03 & .06 & -.05 \\
\hline Self-employed & -.07 & $-.50 * *$ & -.14 & $.48^{* * *}$ & .04 & .05 \\
\hline Service class & $-.21^{*}$ & $-.38^{* * *}$ & $-.25^{* \star *}$ & $-.18^{* *}$ & $-.14^{*}$ & $-.24^{* * *}$ \\
\hline Routine non-manual & .04 & $-.18^{* *}$ & $-.17^{* * *}$ & -.07 & .05 & $-.11^{* * *}$ \\
\hline Skilled manual worker & -.01 & .07 & .02 & $.17^{*}$ & -.01 & $.06^{*}$ \\
\hline Unskilled manual worker & 0 & 0 & 0 & 0 & 0 & 0 \\
\hline Unknown income & .05 & .08 & -.04 & $.17^{* *}$ & .02 & .03 \\
\hline High income & -.05 & -.01 & $-.19^{* * *}$ & $.23^{\star * *}$ & $-.30^{* * *}$ & $-.09^{* * *}$ \\
\hline Middle income & -.11 & .03 & -.04 & $.18^{* *}$ & $-.14^{*}$ & -.01 \\
\hline Low income & 0 & 0 & 0 & 0 & 0 & 0 \\
\hline Rural & .08 & $.12^{* *}$ & .03 & $-.12^{* *}$ & $.17^{* * *}$ & .03 \\
\hline Urban & 0 & 0 & 0 & 0 & 0 & 0 \\
\hline Never married & .07 & -.00 & -.03 & $-.16^{\star *}$ & $-.16^{\star *}$ & $-.07^{* *}$ \\
\hline Divorced or widowed & .03 & .07 & -.03 & -.15 & .02 & -.01 \\
\hline Married & 0 & 0 & 0 & 0 & 0 & 0 \\
\hline Religious & .01 & -.02 & $-.20^{* * *}$ & $.59^{* * *}$ & -.08 & .01 \\
\hline Non-religious & 0 & 0 & 0 & 0 & 0 & 0 \\
\hline Age & -.05 & $-.05^{*}$ & $-.03^{* *}$ & $.03^{*}$ & $-.06^{* * *}$ & $-.29^{\star \star *}$ \\
\hline Education & $-.75^{\star * *}$ & $-.68^{* * *}$ & $-.62^{\star * *}$ & $-.51^{* * *}$ & $-.48^{* * *}$ & $-.60^{* *}$ \\
\hline Satisfaction with economy & $-.12^{* * \star}$ & $-.23^{*}$ & $-.95^{\star * *}$ & $-.81^{* * *}$ & $-.75^{\star * *}$ & $-.76^{\star \star \star}$ \\
\hline Left-right scale & $.91^{* \star *}$ & $1.58^{* * *}$ & $1.31^{* * *}$ & $.85^{\star \star *}$ & $.35^{\star * *}$ & $1.05^{* * *}$ \\
\hline Conservation values & $1.61^{* * *}$ & $1.24^{* * *}$ & $.136^{* * *}$ & $1.54^{* * *}$ & $1.08^{* * *}$ & $1.39^{* * *}$ \\
\hline Nordic countries & - & - & - & - & - & $.48^{* * *}$ \\
\hline Central European countries & - & - & - & - & - & $.15^{\star * *}$ \\
\hline Mediterranean countries & - & - & - & - & - & $.47^{* * *}$ \\
\hline Eastern European countries & - & - & - & - & - & $.46^{* * *}$ \\
\hline Finland & - & - & - & - & - & 0 \\
\hline $\mathrm{R}^{2}$ & .23 & .24 & .23 & .27 & .13 & .24 \\
\hline
\end{tabular}




\section{Discussion}

In this article we set out to examine the Finnish attitudinal climate towards foreignborn settlers in a European context. Finland is an especially interesting case, since the population of the country is still highly homogenous, although very recently it has experienced an increase in foreign-born population.

The analysis shows that in a European comparison Finns do hold comparatively negative attitudes towards increasing the number of foreign-born settlers in the country. Especially immigrants with a different ethnic background and those coming from outside Europe are the least welcomed. However, as we turned to more specific attitudes measured by direct items on economic and cultural threat, Finns no longer differed from other European nations as strongly. Contrary to expectation, Finns show less fear of socio-economic threat than Continental Europeans but more than other Northern Europeans. Worries about the possible cultural threat posed by foreign-born settlers in Finland are on the same level as in other Nordic countries and more rare than in other European countries.

What then accounts for the variation between different segments of the population? We set out to test two core propositions. On the one hand, socio-economic factors should have a clear effect on these attitudes on the individual level. On the other hand it was hypothesized that attitudes depend more on values, ideologies and religiosity than on socio-economic correlates. In the light of this analysis both fears about socio-economic and cultural threat stimulate prejudice. The theories emphasizing either socio-economic or cultural factors should, thus, not be taken as alternatives, but rather as complementary theoretical approaches. All in all, however, Finns show less anxiety about cultural threat than all other Europeans.

This analysis suggests that prejudice is a complicated and multi-faceted phenomenon. Therefore it is not likely that a unitary theoretical explanation of the emergence of negative sentiments concerning foreign-born settlers could be found. Negative sentiments emerge from different causes in different socio-economic and cultural settings. Nevertheless, this analysis supports some generalizations already found in prior research. The most important determinants of prejudice are gender, occupational status, age and especially contact with immigrants, education, economic satisfaction, political orientation and conservation value priorities. The effects of these factors give support to the hypotheses presented above. As expected the perception of threat to socio-economic well-being is most pronounced among the disadvantaged populations in most countries. We also find some gender differences. Men feel more anxious especially about the possible cultural threat posed by immigration. Increasing age seems to correlate with anti-immigrant sentiments in all countries, which gives support to the value-oriented explanation rather than to the socio-economic 
explanation. Moreover, rightist political views clearly correlate with prejudice. Religiosity decreases prejudice in all but Mediterranean countries. Higher levels of education are associated with lower levels of prejudice. Finally, the most important background variables in this analysis are contact with immigrants and conservation value priorities. The former effectively stimulates positive sentiments towards immigrants, refugees and asylum seekers, whereas the latter correlates strongly with negative sentiments towards them.

\section{References}

Adorno, T., E. Frenkel-Brunswik, D.J. Levinson, and R.N. Sanford. 1950. The Authoritarian Personality. New York: Harper \& Brothers.

Allport, G.W. and J.M. Ross. 1967. Personal religious orientations and prejudice. Journal of Personality and Social Psychology 5(3):432-43.

Altemeyer, B. 2003. Why do religious fundamentalists tend to be prejudiced? The International Journal for the Psychology of Religion 13(1):17-28.

Altemeyer, B. and B. Hunsberg. 1992. Authoritariansim, religious fundamentalism, quest, and prejudice. The International Journal for the Psychology of Religion 2(2):113-33.

Bamberg, S., J. Herrmann, S. Kynast, and P. Schmidt. 2001. "Portraits Value Questionnaire" - Ein neues Instrument zur Messung von Schwartz Theorie Grundlegender menschlicher Werte. Unpublished manuscript, University of Giessen.

Bratt, C. 2002. Contact and attitudes between ethnic groups: A survey-based study of adolescents in Norway. Acta Sociologica 45(2):107-25.

Canetti-Nisim, D. and A. Pedahzur. 2003. Contributory factors to political xenophobia in a multi-cultural society: the case of Israel. International Journal of Intercultural Relations 27(3):307-33.

Chandler, R.C. and Y. Tsai. 2001. Social factors influencing immigration attitudes: an analysis of data from the General Social Survey. The Social Science Journal 38(2):177-88.

Duckitt, J. 1992. The social psychology of prejudice. New York: Praeger.

Eisinga, R., J. Billiet, and A. Felling. 1999. Christian religion and ethnic prejudice in crossnational perspective. A comparative analysis of the Netherlands and Flanders (Belgium). International Journal of Comparative Sociology 40(3):375-93.

Ervasti, H. 2002. Unemployment and unemployment policy in Finland. In: Europe's New State of Welfare. Unemployment, Employment Policies and Citizenship, edited by J.G. Andersen, J. Clasen, W. van Oorschot, and K. Halvorsen, pp. 181-193. Bristol: Policy Press.

Feldman, S. 2003. Enforcing social conformity: A theory of authoritarianism. Political Psychology 24(1):41-74.

Frindte, W., F. Funke, and S. Waldzus. 1996. Xenophobia and right-wing-extremism in German youth groups - some evidence against unidimensional misinterpretations. International Journal of Intercultural Relations 20(3/4):463-78.

Giles, M.W. and K. Hertz. 1994. Racial threat and partisan identification. American Political Science Review 88(2):317-26.

Hagendoorn, L. 1993. Ethnic categorization and outgroup exclusion: cultural values and social stereotypes in the construction of ethnic hierarchies. Ethnic and Racial Studies 16(1):26-51.

Hagendoorn, L., R. Drognedijk, S. Tumanow, and J. Hraba. 1998. Inter-ethnic preferences and ethnic hierarchies in the former Soviet Union. International Journal of Intercultural Relations 22(4):483-503.

Heikkilä, E. and S. Peltonen. 2002. Immigrants and integration in Finland. Turku: Institute of Migration. 
Hernes, G. and K. Knudsen. 1992. Norwegians' attitudes towards new immigrants. Acta Sociologica 35(2):123-40.

Inglehart, R. 1997. Modernization and Postmodernization. Cultural, economic and political change in 43 societies. Princeton: Princeton University Press.

Jaakkola, M. 1995. Suomalaisten kiristyvät ulkomaalaisasenteet. Työpoliittinen tutkimus 101. Helsinki: Painatuskeskus.

Jaakkola, M. 1999. Maahanmuutto ja etniset asenteet. Työpoliittinen tutkimus 213. Helsinki: Edita.

Jackman, M.R. and M.J. Muha. 1984. Education and intergroup attitudes: Moral enlightment, superficial democratic commitment or ideological refinement? American Sociological Review 49(5):751-69.

Jowell, R. \& the Central Co-ordinating Team. 2003. European Social Survey 2002/2003: Technical report. London: Centre for Comparative Social Surveys, City University.

Knafo, A. 2003. Authoritarians, the next generation: Values and bullying among adolescent children of authoritarian fathers. Analyses of Social Issues and Public Policy 3(1):199204.

Knigge, P. 1998. The ecological correlates of right-wing extremism in Western Europe. European Journal of Political Research 34(2):249-79.

Mullick, R. and J. Hraba. 2001. Ethnic attitudes in Pakistan. International Journal of Intercultural Relations 25(2):165-79.

Pettigrew, T.F. 1998. Reactions toward the new minorities of Western Europe. Annual Review of Sociology 24(1):77-103.

Raijman, R., M. Semyonov, and P. Schmidt. 2003. Do foreigners deserve rights? Determinants of public views towards foreigners in Germany and Israel. European Sociological Review 19(4):379-92.

Ray, J.J. 1990. The old-fashioned personality. Human Relations 43(3):997-1015.

Rokeach, M. 1968. A theory of organization and change in value-attitude systems. Journal of Social Issues 24(2):528-37.

Scheepers, P., M. Gijsberts, and M. Coenders. 2002. Ethnic exclusionism in European countries: Public opposition to civil rights for legal migrants as a response to perceived ethnical threat. European Sociological Review 18(1):17-34.

Schwartz, S. 1997. Values and culture. In: Motivation and Culture, edited by Donald Munro, John Schumaker and Stuart C. Carr, pp. 69-84. New York: Routledge.

Sherif, M. and C.W. Sherif, 1953. Groups in harmony and tension. New York: Harper Brothers.

Sniderman, P.M., T. Piazza, P.E. Tetlock, and A. Kendrick. 1991. The new racism. American Journal of Political Science 35(2):423-47.

Spencer-Rodgers, J. \& T. McGovern. 2002. Attitudes toward the culturally different: The role of intercultural communication barriers, affective responses, consensual stereotypes, and perceived threat. International Journal of Intercultural Relations 26(6):609-31.

Stouffer, S.A., L.C. De Vinney, and E.A. Suchmen. 1949. The American soldier. New York: Princeton.

Söderling, I. 1997. Maahanmuutto ja elämänhallinta. Väestöntutkimuslaitoksen julkaisu D 30/1997. Helsinki: Väestöliitto.

Tabachnick, B.G. and L.S. Fidell. 2001. Using multivariate statistics. Boston: Allyn and Bacon.

Thalhammer, E., V. Zucha, E. Enzenhofer, B. Salfinger, and G. Ogris. 2001. Attitudes towards minority groups in the European Union. A special analysis of the Eurobarometer 2000 survey on behalf of the European Monitoring Centre on Racism and Xenophobia. Vienna: SORA. Available at http://europa.eu.int/comm/public_opinion/archives/eb/ebs_138_analysis.pdf.

Van der Brug, W., M. Fennema, and J. Tillie. 2000. Anti-immigrant parties in Europe: ideological or protest vote? European Journal of Political Research 37(1):77-102.

Williams, R.M. Jr. 1975. Relative deprivation. In: The idea of social structure, edited by L.A. Closer. New York: Hartcourt Brace Jovanovich. 